\title{
Comparison of land-atmosphere interaction at different surface types in the mid- to lower reaches of the Yangtze River valley
}

\author{
Weidong Guo ${ }^{1,2}$, Xueqian Wang ${ }^{1,2}$, Jianning Sun ${ }^{1,2}$, Aijun Ding ${ }^{1,2}$, and Jun Zou ${ }^{1,2}$ \\ ${ }^{1}$ Institute for Climate and Global Change Research, School of Atmospheric Sciences, Nanjing University, Nanjing, China \\ ${ }^{2}$ Joint International Research Laboratory of Atmospheric and Earth System Sciences, Nanjing, China \\ Correspondence to: W. D. Guo (guowd@nju.edu.cn) and J. N. Sun (jnsun@nju.edu.cn)
}

Received: 17 January 2016 - Published in Atmos. Chem. Phys. Discuss.: 28 January 2016

Revised: 2 July 2016 - Accepted: 4 July 2016 - Published: 8 August 2016

\begin{abstract}
The mid- to lower reaches of the Yangtze River valley are located within the typical East Asian monsoon zone. Rapid urbanization, industrialization, and development of agriculture have led to fast and complicated land use and land cover change in this region. To investigate landatmosphere interaction in this region where human activities and monsoon climate have considerable interaction with each other, micrometeorological elements over four sites with different surface types around Nanjing, including urban surface at Dangxiao (hereafter DX-urban), suburban surface at Xianling (XL-suburb), and grassland and farmland at Lishui County (LS-grass and LS-crop), are analyzed and their differences are revealed. The impacts of surface parameters of different surface types on the radiation budget and land surface-atmosphere heat, water, and mass exchanges are investigated and compared. The results indicate the following. (1) The largest differences in daily average surface air temperature $\left(T_{\mathrm{a}}\right)$, surface skin temperature $\left(T_{\mathrm{s}}\right)$, and relative humidity (RH), which are found during the dry periods between DX-urban and LS-crop, can be up to $3.21^{\circ} \mathrm{C}, 7.26^{\circ} \mathrm{C}$, and $22.79 \%$, respectively. The diurnal ranges of the above three elements are the smallest at DX-urban and the largest at LS-grass, XL-suburb, and LS-crop. (2) Differences in radiative fluxes are mainly reflected in upward shortwave radiation (USR) that is related to surface albedo and upward longwave radiation (ULR) that is related to $T_{\mathrm{s}}$. When comparing four sites, it can be found that both the smallest USR and the largest ULR occur at the DX-urban site. The diurnal variation in ULR is same as that of $T_{\mathrm{S}}$ at all four sites. (3) The differences in daily average sensible heat $(H)$ and latent heat (LE) between DX-urban and LS-crop are larger than 45 and $95 \mathrm{Wm}^{-2}$, respectively. The proportion of latent heat flux in
\end{abstract}

the net radiation $\left(\mathrm{LE} / R_{\mathrm{n}}\right)$ keeps increasing with the change in season from the spring to summer. (4) Human activities have obvious effects on microclimate. The urban heat island (UHI) effect results in a $T_{\mathrm{a}} 2{ }^{\circ} \mathrm{C}$ higher at the urban site than other sites in the nighttime. At the crop site, LE is dominant due to irrigation, and negative $H$ is observed since evaporation cooling leads to low $T_{\mathrm{s}}$. Although $T_{\mathrm{s}}$ is higher at XL-suburb than that at LS-grass, there is no large difference in $T_{\mathrm{a}}$ between the two sites due to the distinct effects of the planted forest.

\section{Introduction}

Land use/land cover change (LULCC) is one of the most important anthropogenic forces to weather and climate change in local, regional and global scale (IPCC, 2013). On earth, over $80 \%$ of the total land surface has been affected by human activities (Sanderson, 2002) in the form of construction, farmland and loss of forest, which is increasing greatly at multiple spatial and temporal scales in regions of different climate regimes (Davin and De Noblet-Ducoudré, 2010; Kalnay and Cai, 2003; Lawrence et al., 2012). Logging and the creation of new farmlands have changed land use in the tropics (DeFries et al., 2002), intensive human activities in temperate regions have changed forests and grasslands to farmlands, and urbanization and industrialization have been intensifying all the time and desert area has been expanding (Gao et al., 2003; Huang et al., 2015; Suh and Lee, 2004). In boreal regions, forests have degraded to grasslands and farmlands due to fire and pest damage as well as logging (Brown et al., 2010; Lohila et al., 2010). 

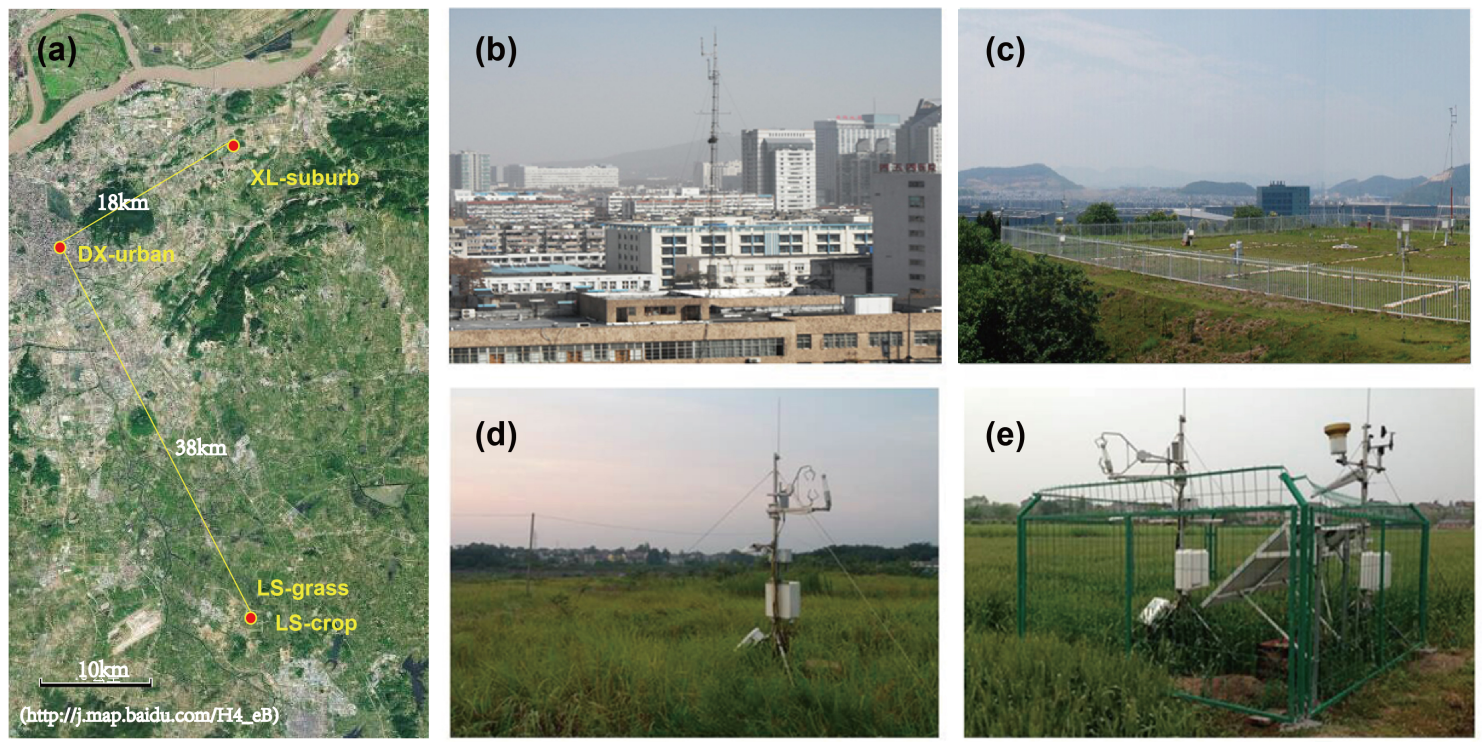

Figure 1. Location (a) and surface types of four field sites at (b) DX-urban, (c) XL-suburb, (d) LS-grass, and (e) LS-crop in Nanjing.

Under the same climate background, the radiation components and surface energy distribution are controlled by characteristic surface factors such as vegetation cover, albedo, and roughness length (Amiro et al., 2006; Feddema et al., 2005; Jin and Roy, 2005) and subsequently affect micrometeorological elements of temperature, humidity, and precipitation. The effect of LULCC on regional and global climate has been documented through the use of climate models. Large-scale vegetation degradation and the development of agriculture and animal husbandry at different scales will lead to decreases in precipitation (McAlpine et al., 2009; Werth and Avissar, 2002), while LULCC will affect the temperature difference between the surface and air temperature and vegetation feedback, such as tropical warming and boreal cooling due to deforestation and the urban heat island effect (Arnfield, 2003; Bounoua et al., 2002; Luyssaert et al., 2014; Pielke et al., 2002).

However, a severe uncertainty in models still exists due to the insufficient knowledge of the surface-atmosphere interaction in response to variations in surface fluxes and energy balance (Bonan, 2008; Wang and Eleuterio, 2001; Pitman et al., 2009). One way to solve this problem is to verify the model and parameterization schemes by driving them with field measurements and observations, which is of high importance in the present study. With the development of a new tool, Fluxnet (Baldocchi et al., 2001), a large number of land surface pair sites were built up in the wild, rural and urban areas, which has produced many significant results. Both management on existing types of land cover and conversion to a different type can affect the local climate (Baldocchi, 2014). Aerodynamically rougher and darker oak savanna has higher $R_{\mathrm{n}}, H$, and $T_{\mathrm{a}}$ than the grassland under the same climate conditions (Baldocchi and Ma, 2013; Baldocchi et al., 2004); deforestation would have a cooling effect on $T_{\mathrm{a}}$ in mid- to high latitudes and a warming effect in low latitude (Lee et al., 2011); wildfires on different land cover cause different effects (Krishman et al., 2012; Montes-Helu et al., 2009); and the management practices of rangeland and cropland or the change in crop types can influence the energy balance and water budget (Alberto et al., 2009, 2011; Baldocchi and Rao, 1995; Coulter et al., 2006; Masseroni et al., 2014). Furthermore, in a city, LE at the residential site is less dependent on short-term precipitation than at the grass site and $H$ is related to land cover and building intensity (Offerle et al., 2006).

China, with the largest population in the world, is one of the fastest growing and urbanizing economies. Thus, LULCC has an significant influence on the regional to global climate change by altering the land surface energy and water flux in China (Zhao and Pitman, 2005; Suh and Lee, 2004; Chen et al., 2014). Most field sites are built in arid and semiarid regions. In the northeastern ecotone between agriculture and animal husbandry, farmland has greater roughness and energy fluxes than the grassland in Tongyu (Feng et al., 2012) but less than the reed wetland in Panjin ( $\mathrm{Li}$ et al., 2009). In the degraded grassland in western China, the oasis-desert transition zone is a cold source relative to the Gobi in Dunhuang (Wang et al., 2005; Zhang and Huang, 2004), and energy fluxes are different over different land surface due to vegetation, precipitation, and soil moisture in the Loess Plateau (Huang et al., 2008; Guan et al., 2009; Wang et al., 2010). Moreover, rapid urban expansion has changed heat fluxes in the Pearl River delta considerably (Lin et al., 2009) and has increased sensible heat flux in Beijing (Zhang et al., 2009). There are obvious differences between different surface types, including air temperature, soil moisture, and surface radiation and energy budget (Zhao et al., 2013; Zhang et 
al., 2014). In the monsoon region, it is worth noting that land cover change both in the Tibetan Plateau and Inner Mongolia from vegetated to bare land not only changed the local surface heat and water flux but also weakened East Asian summer monsoon circulation and precipitation (Xue, 1996; $\mathrm{Li}$ and Xue, 2010). Even though the changes in surface heat fluxes can influence monsoon onset or weakening and precipitation (Hsu and Liu, 2003; Fu and Yuan, 2001; Qiu, 2013; Xue et al., 2004), studies based on field observations are very limited in the East Asian monsoon region (Bi et al., 2007), especially over the mid- to lower reaches of the Yangtze River valley.

The mid- to lower reaches of the Yangtze River valley are located in the typical East Asian monsoon region, where the land use and land cover have been experiencing rapid changes with more complicated land use types due to the rapid urbanization and industrialization and the development of agriculture and animal husbandry. Interaction between human activities and monsoon climate is most intensive in this region. Under the background of monsoon climate, studies about the differences in the diurnal and seasonal variations in the land-atmosphere interaction over various surface types are almost nonexistent in this region.

In order to better understand the characteristics and mechanisms for the exchanges of mass, energy, and water vapor between the land surface and atmosphere in the mid- to lower reaches of the Yangtze River valley, in the present study we analyze observations collected at several ground sites over different surface types around Nanjing. These sites include a school site in the urban area (hereafter DX-urban), the Xianling site in suburban Nanjing (XL-suburb), a grassland site (LS-grass), and a farmland site (LS-crop) in Lishui County, which is located in the countryside. Data used in this study were collected at these sites in the spring and summer of 2013. The goals of the study are (1) to compare the seasonal and diurnal variation in micrometeorological elements over different land surface types, (2) to reveal the differences in surface radiation budget and energy distribution between various surface types, and (3) to calculate important surface parameters over different surface and investigate the feedback of different surface types to the atmosphere and its impact on local climate. The mechanisms for the surface-atmosphere feedback will be further investigated. This study will fill the gap of observation scarcity in land-atmosphere interaction in the mid- to lower reaches of the Yangtze River valley and provide scientific evidence for regional climate simulation and climate change prediction.

\section{Data and methodology}

\subsection{Introduction of field sites}

The observations used in this study were collected at four field sites located in urban, suburban, and countryside areas of Nanjing. The four sites are referred to as DX-urban, XLsuburb, LS-grass, and LS-crop hereafter.

The DX-urban site (Fig. 1a) is located in Baixia District of Nanjing $\left(32^{\circ} 2^{\prime} 24 \mathrm{~N}, 118^{\circ} 47^{\prime} 24 \mathrm{E}\right)$, which is the central urban area of Nanjing. Residential and commercial buildings are dominant within a $500 \mathrm{~m}$ radius around the DX-urban site, and thereby the land surface type is a typical urban surface at this site. Average height of buildings is $19.7 \mathrm{~m}$, and the building coverage is up to $70 \%$.

The XL-suburb site (Fig. 1b) is the key station in the experiment of Station for Observing Regional Processes of the Earth System, Nanjing University (SORPES-NJU). It is located at $32^{\circ} 7^{\prime} 14^{\prime \prime} \mathrm{N}, 118^{\circ} 57^{\prime} 10^{\prime \prime} \mathrm{E}, 43 \mathrm{~m}$ above sea level (ma.s.1.), in the eastern suburb of Nanjing, an upwind area along the prevailing wind direction in Nanjing (Ding et al., 2013). The distance between the XL-suburb site and DXurban site is $18 \mathrm{~km}$. Within the $50 \mathrm{~m} \times 50 \mathrm{~m}$ area at the XLsuburb site, the grass height is $7 \mathrm{~cm}$. Outside the site area are woodlands from afforestation with a height of around $3 \mathrm{~m}$. This site is located inside the Xianling campus of Nanjing University. Since its operation in 2011, continuous observations have been measured through a suite of instruments. The observations include conventional meteorological measurements at various levels, surface energy budget measurements, boundary layer meteorological elements measurements, surface radiation measurements, atmosphere components and aerosols measurements, etc. The data used in this study are standard measurements at half-hour intervals.

The site $\left(31^{\circ} 43^{\prime} 08 \mathrm{~N}, 118^{\circ} 58^{\prime} 51 \mathrm{E}\right)$ in Lishui County is taken as a satellite site of the SORPES-NJU (Station for Observing Regional Processes of the Earth System, Nanjing University). The distance between the Lishui site and DXurban site is $38 \mathrm{~km}$. The Lishui site consists of a pair of observational sites, one over the grassland (LS-grass, Fig. 1c) and the other (LS-crop, Fig. 1d) over the farmland nearby. The grass height is about $60 \mathrm{~cm}$ at LS-grass, and the observation period was from January 2012 to February 2014. Rice grows at LS-crop in the summer (mid-June to early November) and winter wheat grows in the winter (from mid- to late November to early June of the next year). A series of agricultural activities occurred in the cropland, including winter wheat harvest in late May and straw burning and rice irrigation in early June. The maximum height of wheat is $75 \mathrm{~cm}$. The observation period at LS-crop is from January 2013 to February 2014. The distance between the two sites at Lishui is $1.62 \mathrm{~km}$.

\subsection{Micrometeorological measurements}

The instruments used at the XL-suburb site include an automatic weather station, eddy-covariance system, energy balance system, and soil temperature/humidity observation system. Table 1 lists the major measured variables, ranges, observation heights, and instrument models. The same measurement method is applied at the XL-suburb, LS-grass, and 
Table 1. Instruments, measurement ranges, measurement heights, and instrument models.

\begin{tabular}{llll}
\hline Instrument name & Range & Measurement height & Instrument type \\
\hline Wind speed sensor & $0-45 \mathrm{~m} \mathrm{~s}^{-1}$ & $2.0 \mathrm{~m}$ & Met One, 014A-L \\
Humidity probe & $0-100 \%$ & $2.0 \mathrm{~m}$ & Vaisala, HMP45C-L \\
Temperature probe & $-45-60^{\circ} \mathrm{C}$ & $2.0 \mathrm{~m}$ & Vaisala, HMP45C-L \\
Barometric pressure sensor & $600-1060 \mathrm{mbar}$ & $8.0 \mathrm{~m}$ & Vaisala, CS105 \\
Tipping bucket rain gage & $0-15 \mathrm{~mm}$ & $0.3 \mathrm{~m}$ & TE525MM-L, R. M. Young \\
Pyranometer (SW flux) & $0-1200 \mathrm{~W} \mathrm{~m}^{-2}$ & $1.5 \mathrm{~m}$ & Kipp \& Zonen, CM21 \\
Pyrgeometer $(\mathrm{LW}$ flux) & $0-700 \mathrm{~W} \mathrm{~m}^{-2}$ & $1.5 \mathrm{~m}$ & Kipp \& Zonen, CG4 \\
3-D Sonic anemometer & & $3.0 \mathrm{~m}$ & Campbell Sci., CSAT3 \\
Opened path infrared $\mathrm{CO}_{2} / \mathrm{H}_{2} \mathrm{O}$ analyzer & & $3.0 \mathrm{~m}$ & Li-Cor, LI7500 \\
Water content reflectometer & $0-70 \mathrm{~V} / \mathrm{V}^{\circ}$ & $5,10,20,40,80 \mathrm{~cm}$ & Campbell Sci., CS616-L \\
Soil temperature profile & $-50-70{ }^{\circ} \mathrm{C}$ & $2,5,10,20,50,80 \mathrm{~cm}$ & Hukseflux, STP01-L \\
Soil heat flux plate & $-300-300 \mathrm{~W} \mathrm{~m}{ }^{-2}$ & $8 \mathrm{~cm}$ & Hukseflux, HFP01SC-L \\
\hline
\end{tabular}

LS-crop sites. At the DX-urban site, there is no measurement of soil moisture and soil temperature. The eddy-covariance and energy balance system instruments are installed at the top of a $36.5 \mathrm{~m}$ high tower on the roof of the building, which is $22 \mathrm{~m}$ high. The air temperature and humidity can be observed by the tower-mounted system $9 \mathrm{~m}$ above the roof.

The automatic weather station (AG1000, Campbell Scientific) measures micrometeorological elements of temperature, pressure, relative humidity, wind speed and direction, precipitation, and surface radiation components of upward/downward shortwave and longwave radiation fluxes. $T_{\mathrm{S}}$ is measured by infrared detection sensor (IRTS-P, Apogee).

Momentum and sensible and latent heat fluxes are measured by the eddy-covariance system (EC3000, Campbell Scientific), which includes a three-dimensional sonic anemometer (CSAT3) and an infrared analyzer (LI7500) at $3 \mathrm{~m}$ height. The sampling frequency is $10 \mathrm{~Hz}$ for measurements by the data acquisition instrument (CR5000). Strict correction and quality control (Foken er al., 2004) have been performed for all the turbulence measurements. Coordinate rotation correction (Wilczak et al., 2001), frequency response correction (Moore, 1986), and WPL correction (Webb et al., 1980) are applied in this study.

The soil heat flux plate (HFP01SC-L, Hukseflux) is at a depth of $8 \mathrm{~cm}$. At the LS-grass and LS-crop sites, the soil heat flux is measured at 5 and $10 \mathrm{~cm}$ below the ground, respectively. Soil temperature and moisture at 5, 10, 20, 40, and $80 \mathrm{~cm}$ are measured using a soil temperature profile sensor (STP01-L, Hukseflux) and water content analyzer (S616-L, Campbell Scientific). No soil temperature and moisture measurements are conducted at the DX-urban site.

The data collected at the spring and summer (from March to August) of 2013 are used in the present study. This is because the measurements are relatively complete during this period, which is also the time when land-atmosphere interaction is strong.

\subsection{Methodology}

\subsubsection{Distribution of surface energy}

In the surface with fractional vegetation cover, surface energy budget can be expressed as

$R_{\mathrm{n}}=H+L_{E}+G_{0}+R_{e}$,

where $R_{\mathrm{n}}$ is the net radiation which can be calculated by $R_{\mathrm{n}}=\mathrm{DSR}+\mathrm{DLR}-\mathrm{USR}-\mathrm{ULR}$. The four radiation components in this equation are respectively downward shortwave radiation (DSR), downward longwave radiation (DLR), upward shortwave radiation (USR), and upward longwave radiation (ULR). $H$ and LE are the sensible and latent heat fluxes, respectively, $G_{0}$ is the soil heat flux at the surface, $R_{e}$ is the remaining term, which is associated with the photosynthesis and respiration of plants as well as vegetation and soil thermal storage, etc. (Burba et al., 1999; Harazono et al., 1998). While in the urban areas, the energy balance must take anthropogenic and net storage heat flux but not $\mathrm{G}_{0}$ into consideration (Oke and Cleugh, 1987). In this paper, we only discuss the relationship between $H, \mathrm{LE}$, and $R_{\mathrm{n}}$ on the basis of the observation.

$R_{\mathrm{n}}$ can be calculated from the four radiation components. Sensible and latent heat fluxes are calculated by the following equations:

$$
\begin{aligned}
H & =\bar{\rho} c_{\mathrm{p}} \overline{w^{\prime} T^{\prime}}, \\
\mathrm{LE} & =\bar{\rho} L_{v} \overline{w^{\prime} q^{\prime}},
\end{aligned}
$$

where $\rho, c_{\mathrm{p}}$, and $L$ are respectively the air density $\left(\mathrm{kg} \mathrm{m}^{-3}\right)$, the specific heat capacity at constant pressure $\left(\mathrm{J} \mathrm{kg}^{-1} \mathrm{~K}^{-1}\right)$, and latent heat of vaporization $\left(\mathrm{J} \mathrm{kg}^{-1}\right) . w^{\prime}, T^{\prime}$, and $q^{\prime}$ are perturbations of vertical velocity $\left(\mathrm{m} \mathrm{s}^{-1}\right)$, temperature $(\mathrm{K})$, and mixing ratio of water vapor $\left(\mathrm{g} \mathrm{kg}^{-1}\right)$, respectively. Strict quality control has been conducted for all flux measurements. 

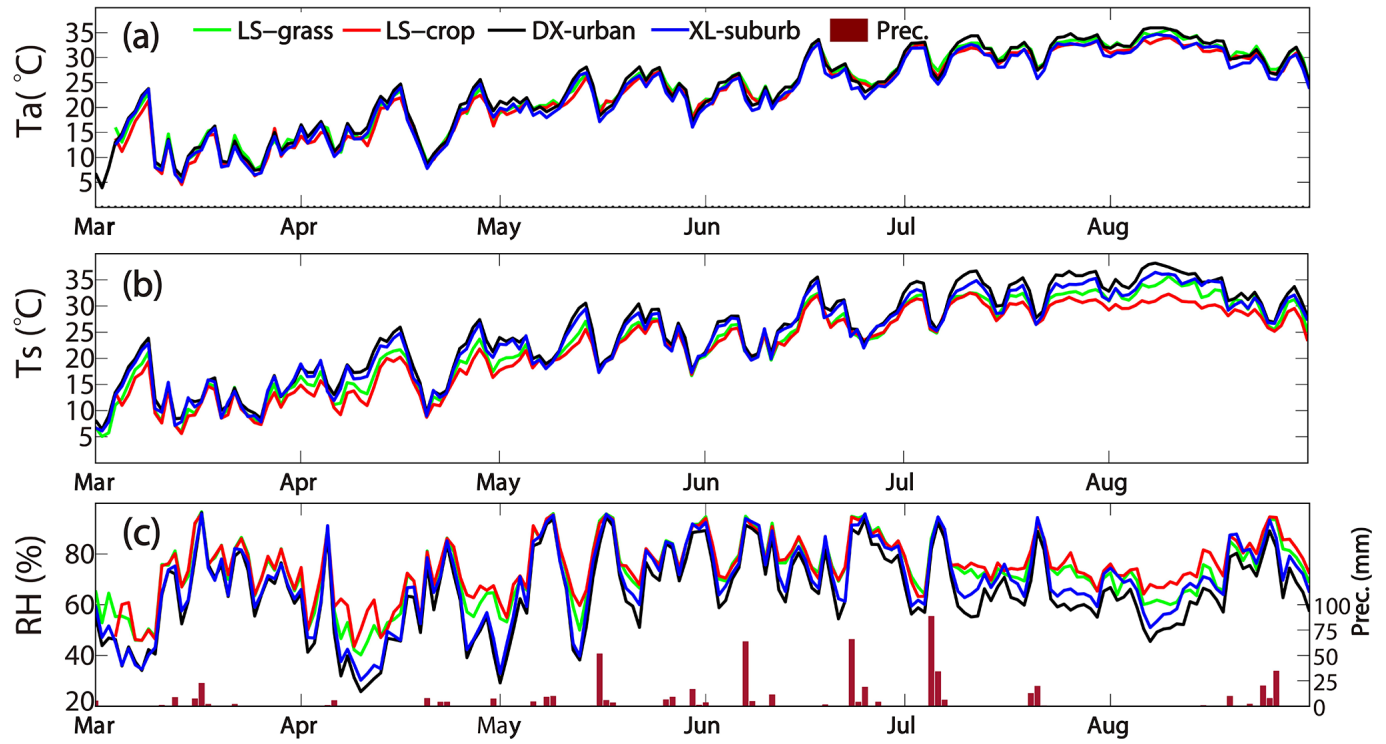

Figure 2. Daily variations in (a) air temperature, (b) surface temperature, and (c) relative humidity at the four sites in Nanjing from March to August 2013.

\subsubsection{Parameters related to the land surface process}

Surface albedo can be calculated based on the equation below (Zhang et al., 2004):

$\alpha=\frac{\sum \mathrm{USR}}{\sum \mathrm{DSR}}$,

where both USR and DSR are at half-hour intervals. This method can to a certain degree avoid the adverse influence of low albedo on the calculation of daily average solar radiation when the solar zenith angle is too low. Daily average albedo is the ratio between the upward and downward solar radiation at half-hour intervals during the period from 06:00 to $18: 00 \mathrm{LST}$.

Following the same approach used in Li et al. (2015), the Bowen ratio is calculated based on the ratio of $H$ and LE. It is expressed as

$\beta=\frac{\sum H}{\sum \mathrm{LE}}$.

$H$ and $L_{E}$ are sensible and latent heat fluxes at half-hour intervals, respectively. The daily Bowen ratio is the ratio between the sum of sensible and latent heat fluxes at half-hour intervals over the entire day. The ratio between sensible and latent heat fluxes at the same time is taken as the Bowen ratio at that same time.

Following the independent method proposed by Chen et al. (1993), which determines $z$ at $0 \mathrm{~m}$ using only the mean wind speed and turbulence measured by ultrasonic anemometer, we fit the non-dimensional wind speed $k u / u^{*}$ to the stability parameter $z / L$ in a double logarithmic coordinate and obtain the value of $k u / u_{*}$ under neutral conditions.
This is then applied to wind profile equation under neutral conditions and yields

$z_{0 \mathrm{~m}}=(z-d) e^{-\frac{k u}{u_{*}}}$,

where $u$ is the horizontal wind speed $\left(\mathrm{m} \mathrm{s}^{-1}\right) ; k$ is the Von Kármán constant, which is set to 0.4 in this study (Prueger et al., 2004); $z$ is the height of the instrument probe (m); $d$ is the zero displacement, which is $2 \mathrm{~m}$ at the XL-suburb site, $0.4 \mathrm{~m}$ at the LS-grass site, and $0.5 \mathrm{~m}$ at the LS-crop site; $u^{*}$ is the friction velocity $\left(\mathrm{m} \mathrm{s}^{-1}\right)$; and $z_{0 \mathrm{~m}}$ is the aerodynamic roughness length. Liu (2015) verified this independent method using measurements from the semiarid regions of China.

\section{Results and discussion}

\subsection{Differences in micrometeorological elements}

The year of 2013 was a period of extreme drought in southern China, with precipitation decreasing by more than $78 \%$ of the average amount in summer, breaking the historical record over the past 50 years (Yuan et al., 2016), especially in the mid- to lower reaches of the Yangtze River valley (Han and He, 2014). Figure 2 shows the daily variations in air temperature, surface temperature, and relative humidity at the four field sites. Surface temperature is calculated based on measured upward and downward longwave radiation and the Stefan-Boltzmann law. Realistic daily changing trends of temperature and humidity are displayed for the four sites, and maximum values of air temperature and surface temperature both occur in August. The changing trend of relative humidity is similar to that of precipitation, and the relative humidity tends to reach saturation at stations where there is more 
Table 2. Seasonal averages of air temperature, surface temperature, and relative humidity at the four sites.

\begin{tabular}{llrrrrrrrr}
\hline \multirow{2}{*}{$\begin{array}{l}\text { Micrometeorological } \\
\text { element }\end{array}$} & \multicolumn{2}{c}{ LS-grass } & \multicolumn{2}{c}{ LS-crop } & \multicolumn{2}{c}{ DX-urban } & \multicolumn{2}{c}{ XL-suburb } \\
\cline { 3 - 9 } & Site name & MAM & JJA & MAM & JJA & MAM & JJA & MAM & JJA \\
\hline Average & $T_{\mathrm{a}}\left({ }^{\circ}\right)$ & 17.29 & 29.85 & 16.44 & 29.02 & 17.50 & 29.92 & 16.53 & 28.64 \\
& $T_{\mathrm{S}}\left({ }^{\circ}\right)$ & 17.23 & 29.62 & 16.02 & 28.02 & 18.76 & 31.23 & 17.98 & 30.12 \\
& $\mathrm{RH}(\%)$ & 69.51 & 76.60 & 71.41 & 78.53 & 60.88 & 68.61 & 63.44 & 73.54 \\
\hline Diurnal range & $T_{\mathrm{a}}\left({ }^{\circ}\right)$ & 9.04 & 6.83 & 8.32 & 6.07 & 7.36 & 5.06 & 7.91 & 5.77 \\
& $T_{\mathrm{S}}\left(^{\circ}\right)$ & 14.51 & 11.67 & 12.22 & 7.77 & 10.64 & 9.26 & 16.19 & 12.46 \\
& $\mathrm{RH}(\%)$ & 33.03 & 27.36 & 35.21 & 25.37 & 23.29 & 20.40 & 25.73 & 21.00 \\
\hline
\end{tabular}

precipitation and higher temperature. Figure 2 shows clearly that large differences in temperature and humidity between the four sites mainly appear at April and August, when precipitation is relatively low. The largest air temperature difference of $3.21^{\circ} \mathrm{C}$ is found between the DX-urban and LS-crop sites at the beginning of August, and the largest surface temperature difference is $7.26^{\circ} \mathrm{C}$. The largest relative humidity difference is $22.79 \%$. Apparently, even in the same climate background, there exist significant differences in micrometeorological elements between various surface types. Such differences are more distinct when there is no precipitation or precipitation is relatively low. Generally, surface temperature increases when vegetation cover fraction decreases except in the farmland, which is affected by irrigation. This is consistent with findings from some experiments in the midlatitudes of North America (X. Lee et al., 2011; Li et al., 2015). Table 2 clearly indicates that, except that the minimum summer temperature is found at the XL-suburb site, extremely high/low values of seasonal average air temperature, surface temperature, and relative humidity all occur at either the LS-crop site or DX-urban site, which are the two sites that are most affected by human activities.

Figure $3 \mathrm{a}$ and $\mathrm{b}$ suggest that the diurnal variations in both air temperature and surface temperature exhibit a single-peak feature in the spring and summer. The minimum value occurs at 07:00 LST, and the maximum value occurs in the afternoon. The variation in air temperature lags that of surface temperature. The peak time of both air and surface temperature in spring lags that in summer. Except for the LS-crop site, surface temperature is higher than air temperature in the other three sites. Nighttime air temperature and surface temperature at the DX-urban site are higher than that at other sites by nearly $2{ }^{\circ} \mathrm{C}$ due to the urban heat island effect. However, this effect is not typical in daytime; the extreme drought weakens this urban heat island (UHI) and even causes the peak temperature at the suburban site and grass site to be higher than the urban site. Natural drought may not have a large effect at the urban site or crop site because of human activities such as watering or irrigation, but at the grass site and suburb site evaporation cooling is distinctly decreased. Comparing the land surfaces that have vegetation cover, the grass height is low at the XL-suburb site and the peak surface temperature variation is large, with the largest temperature being up to $37.61{ }^{\circ} \mathrm{C}$. The peak surface temperature remains low at the LS-crop site due to irrigation, and even lower than the daily maximum air temperature in the summer. The peak surface temperature at the LS-crop site is only $32.4{ }^{\circ} \mathrm{C}$.

Due to the difference of radiation budget on land surface between daytime and nighttime, diurnal surface temperature range is larger than the diurnal range of air temperature. Comparing the diurnal temperature ranges at the four sites, it is found that the diurnal air temperature and surface temperature ranges are 4.79 and $9.26^{\circ} \mathrm{C}$ in the spring, respectively, which are relatively small. In the summer, the LS-crop site is covered by water due to irrigation and the diurnal surface temperature range is only $7.77^{\circ} \mathrm{C}$, which is the minimum among all four sites. The diurnal air temperature range is $6.86^{\circ} \mathrm{C}$ at the LS-grass site in the summer, and the range is relatively large among all the sites. At the same time, the diurnal surface temperature range at the XL-suburb site is $12.46^{\circ} \mathrm{C}$ in the summer, the largest among the four sites. Despite the large diurnal surface temperature range at the XL-suburb site, air temperature and diurnal air temperature ranges are not that large. This is because the afforested woodlands surrounding the XL-suburb site promote heat flux exchange between the surface and atmosphere.

Figure $3 \mathrm{c}$ shows that the relative humidity is always larger in the summer than in the spring. Daily maximum relative humidity occurs at around 07:00 in the morning, and the minimum value occurs at 16:00 in the afternoon. The occurrence of the maximum and minimum values in the spring lags that in the summer. The maximum value is found at LS-crop, with a summer average maximum value of $90.34 \%$. The smallest relative humidity is found at the DX-urban site, where the maximum summer average humidity is only $58.72 \%$. The diurnal relative humidity range at the four sites is larger in the spring than in the summer, and the largest value is found at the LS-crop site in the spring and at LS-grass in the summer, with values of 39.03 and $27.36 \%$, respectively. The diurnal relative humidity range is the smallest at the DX-urban site, which is $23.29 \%$ in the spring and $20.40 \%$ in the summer. Figure 3 clearly indicates that different surface types can lead 

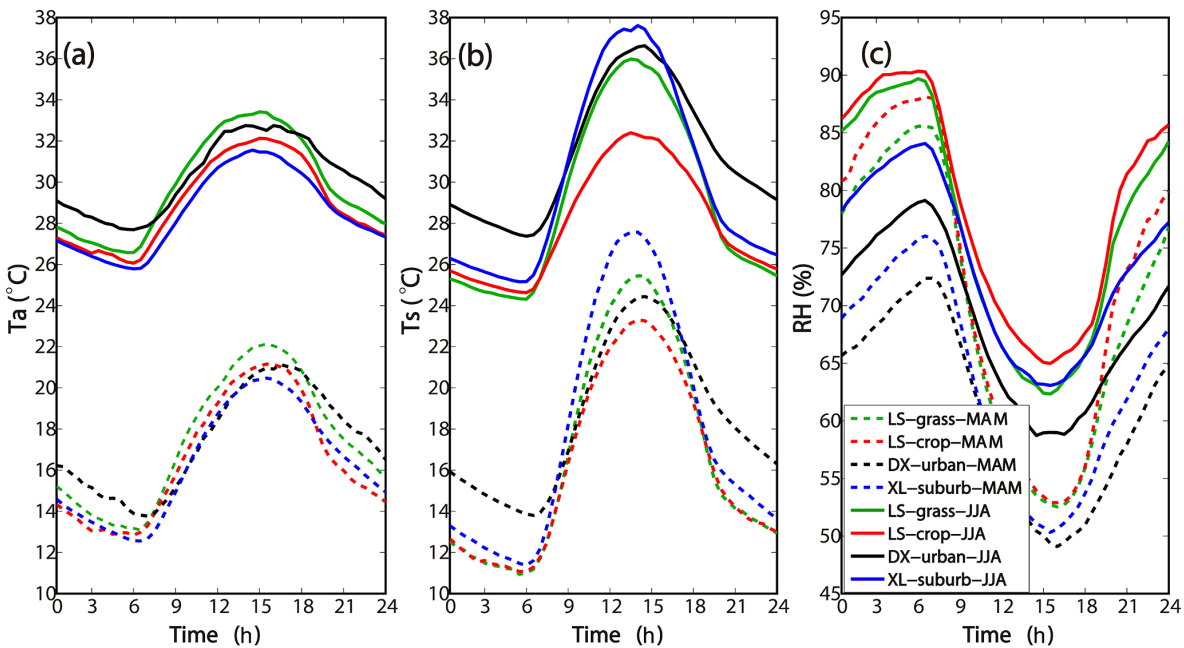

Figure 3. Diurnal variations in (a) air temperature, (b) surface temperature, and (c) relative humidity at the four sites in Nanjing in the spring and summer.
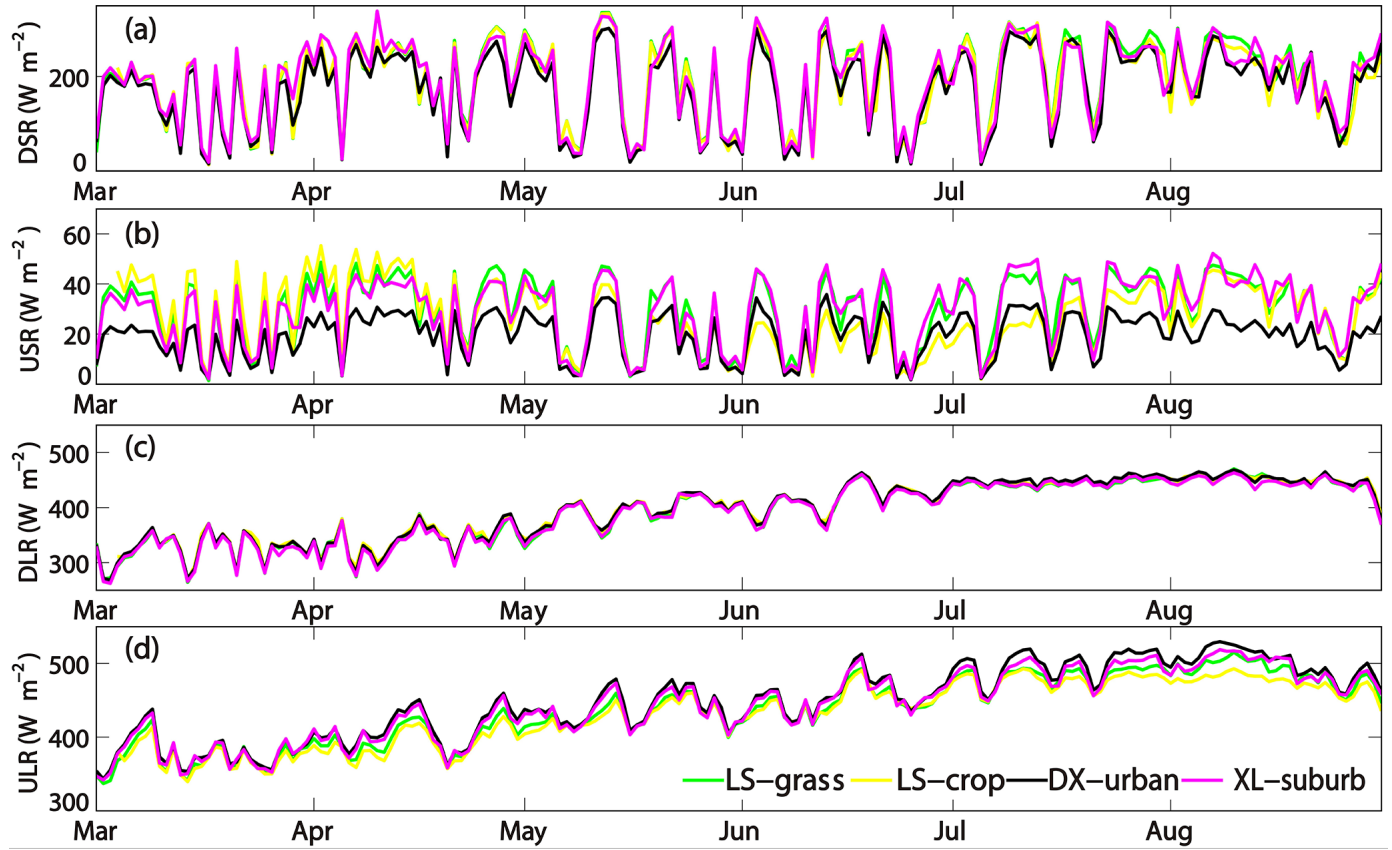

Figure 4. Daily variation in (a) downward shortwave radiation (DSR), (b) upward shortwave radiation (USR), (c) downward longwave radiation (DLR), and (d) upward longwave radiation (ULR) at the four sites in Nanjing.

to differences in surface temperature and impose significant impacts on micrometeorological elements such as air temperature and relative humidity (Krishnan et al., 2012; Luyssaert et al., 2014).

\subsection{Surface net radiation and energy distribution}

\subsubsection{Distribution of net radiation}

Figure 4 displays the daily variation in the four components of surface radiation flux. DSR is mainly affected by clouds and aerosols in the atmosphere. In the monsoon region of the mid- to lower reaches of the Yangtze River valley, cloudy and rainy weather is dominant during the period of May to July, leading to lower shortwave radiation despite the higher so- 

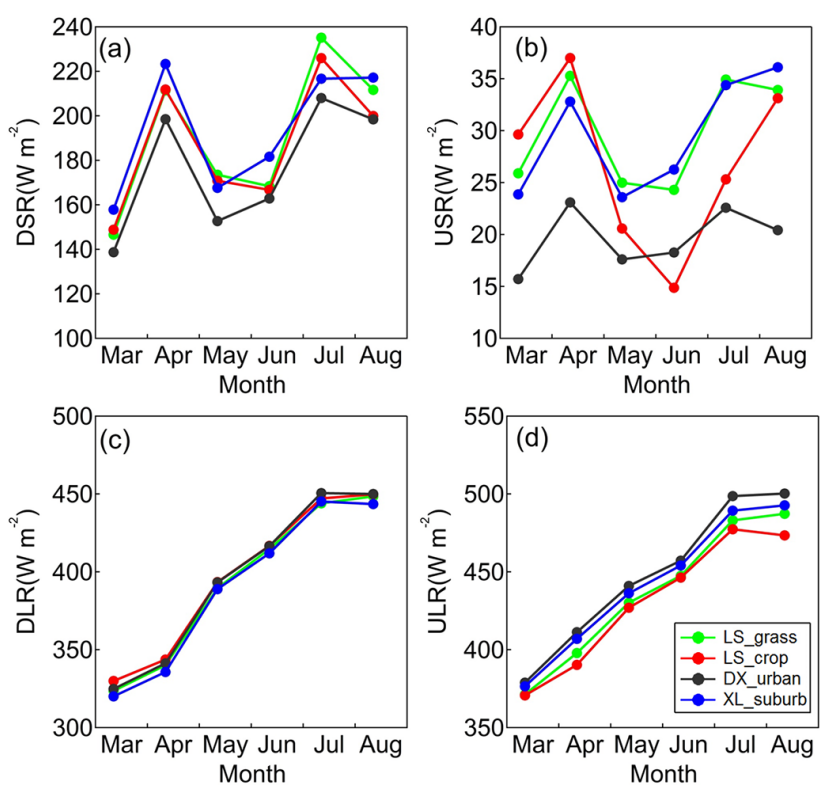

Figure 5. Monthly variation in (a) downward shortwave radiation (DSR), (b) upward shortwave radiation (USR), (c) downward longwave radiation (DLR), and (d) upward longwave radiation (ULR) at the four sites in Nanjing.

lar zenith angle. Under the same climate background, DSR and DLR are similar at the four sites. However, large differences are found in USR and ULR at the four sites. This is because USR is related to surface albedo while ULR is associated with surface temperature. Daily maximum values of USR and ULR both occur in early August. The maximum values of USR are $48.67,55.29,35.80$, and $52.19 \mathrm{Wm}^{-2}$ at the LS-grass, LS-crop, DX-urban, and XL-suburb sites, respectively. The maximum values of ULR at the four sites are $515.22,492.78,529.59$, and $518.81 \mathrm{Wm}^{-2}$, respectively.

USR changes following the changes in DSR and surface albedo. Variability in monthly average USR (Fig. 5b) is similar to that in DSR (Fig. 5a), and both are the smallest at the DX-urban site. However, compared to that at other sites, the USR at the LS-crop decreases rapidly from May and reaches its minimum of $14.87 \mathrm{Wm}^{-2}$ at the end of June. This is because of the albedo decrease at the LS-crop site, which is caused by straw burning at the end of May after the winter wheat harvest. Rice starts growing from late June onwards, and the USR at the LS-crop site becomes similar to that at other sites by August. The ULR remains largest at the DXurban site and smallest at the LS-crop site, which is attributed to the increases in vegetation cover fraction from May to August and irrigation at the LS-crop site. The difference in ULR between the DX-urban and LS-crop can be up to $26.9 \mathrm{Wm}^{-2}$ in August.

With the same weather and climate background, there are no significant differences in DSR and DLR among the four sites, despite their distinct seasonal differences. The maxi- mum daily DSR are around 550 and $600 \mathrm{Wm}^{-2}$ in the spring and summer, respectively, and the maximum daily DLR is about 370 and $450 \mathrm{Wm}^{-2}$ in the spring and summer, respectively. Figure $6 \mathrm{c}$ shows that the maximum daily average USR at XL-suburb, LS-grass, and DX-urban grows to 90.35 , 84.79 , and $59.49 \mathrm{Wm}^{-2}$ in the summer. Unlike these three sites, USR at the crop site decreases by $16.98 \mathrm{Wm}^{-2}$ from spring to summer due to the continuous lower albedo from June to early July. The diurnal variation in ULR (Fig. 6d) depends on diurnal variation in surface temperature (Fig. 2b). The largest ULR occurs at the XL-suburb site in the daytime and at the DX-urban site in the nighttime. The maximum ULR and diurnal ULR range are both the smallest at the LS-crop site due to irrigation.

\subsubsection{Surface energy distribution}

Land-atmosphere energy exchange is the driving force for the local climate and is greatly influenced by climate change (Reale and Dirmeyer, 2000; Li et al., 2009). Figure 7 shows the daily variation in net radiation $\left(R_{\mathrm{n}}\right)$, sensible heat flux $(H)$, and latent heat flux (LE). $R_{\mathrm{n}}$ and DSR have the similar changing trends and both are small during the monsoon precipitation period. The average $R_{\mathrm{n}}$ during the growing season is different over different surface types, and the values are $126.55,118.40,112.58$, and $105.08 \mathrm{Wm}^{-2}$ at the LS-crop, LS-grass, XL-suburb, and DX-urban sites, respectively. The average value of $H$ during the growing season is 4.62, 39.99, 26.13 , and $53.48 \mathrm{Wm}^{-2}$, respectively, at the four sites, while $\mathrm{LE}$ is $74.11,53.59,59.73$, and $34.45 \mathrm{Wm}^{-2}$, respectively. The above results suggest that, under the same large-scale forcing, there exist distinct differences in radiation and turbulent fluxes over different surface types. Such kinds of differences are the largest between the LS-crop and DX-urban sites, where human activities are the most intensive among the four sites. During the non-precipitation period, differences in $R_{\mathrm{n}}$ and $H$ are large in July and August, with absolute values of differences up to 79.88 and $166.56 \mathrm{Wm}^{-2}$, respectively. At the beginning of April, with little precipitation and insufficient soil moisture content, irrigation at the LS-crop site leads to the LE difference to be up to $107.87 \mathrm{Wm}^{-2}$. The above differences are largely caused by the difference in vegetation cover at the surface and are associated with the growth of vegetation and accompanying cost of water.

Monthly average $R_{\mathrm{n}}$ becomes largest in July, and the value at LS-crop is $170.37 \mathrm{Wm}^{-2}$. After the rainy season starts, the proportion of LE in $R_{\mathrm{n}}$ gradually increases. Although the monthly variation in $R_{\mathrm{n}}$ are similar at the four sites (Fig. 8a), there exist large differences in sensible and latent heat flux (Fig. 8b, c). $H$ is smallest at the LS-crop. Rice planting starts in mid-June and the surface is covered by water. Negative sensible heat flux occurs in July and August at LS-crop site. The difference in sensible heat flux between the LS-crop and DX-urban sites is $44.86 \mathrm{Wm}^{-2}$. The change in LE is opposite to that in H. LE becomes largest in July and August, with val- 

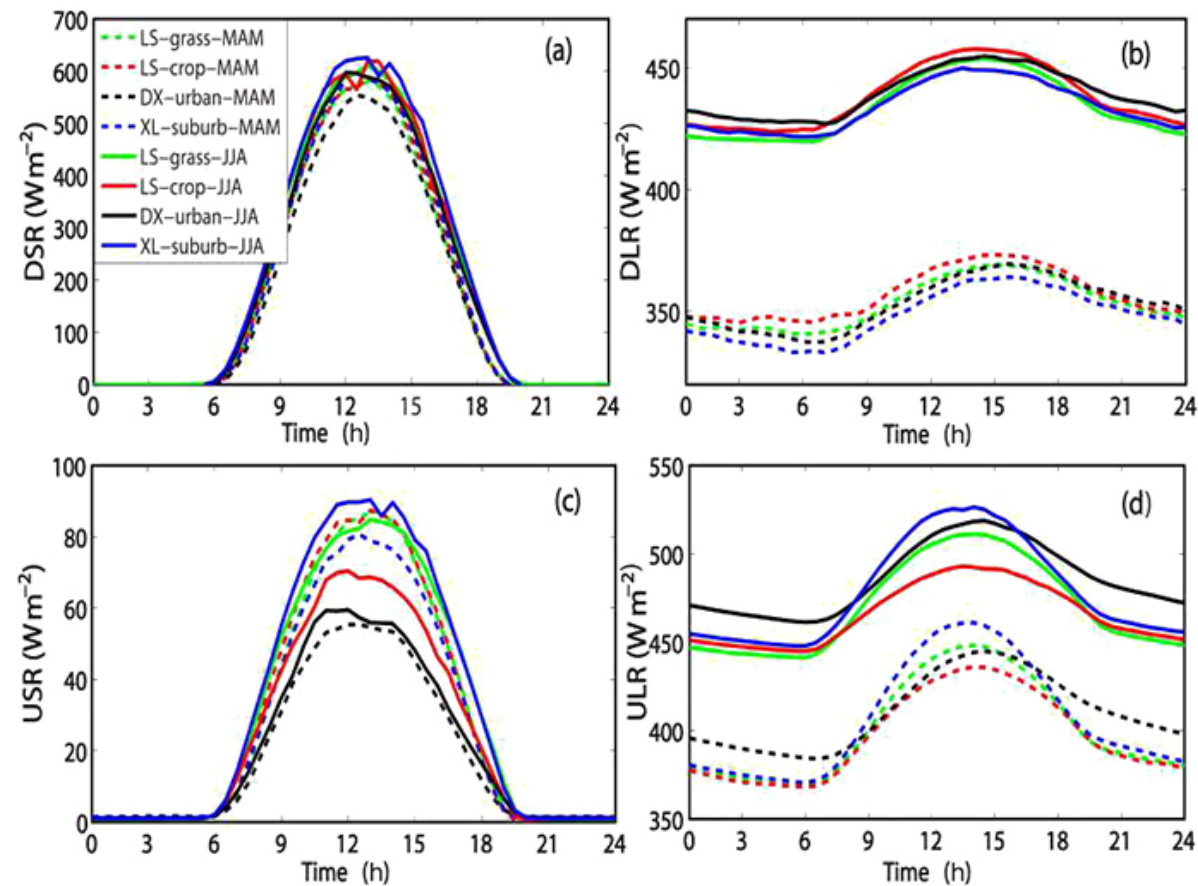

Figure 6. Diurnal variation in (a) downward shortwave radiation (DSR), (b) downward longwave radiation (DLR), (c) upward shortwave radiation (USR), and (d) upward longwave radiation (ULR) at the four sites in Nanjing.
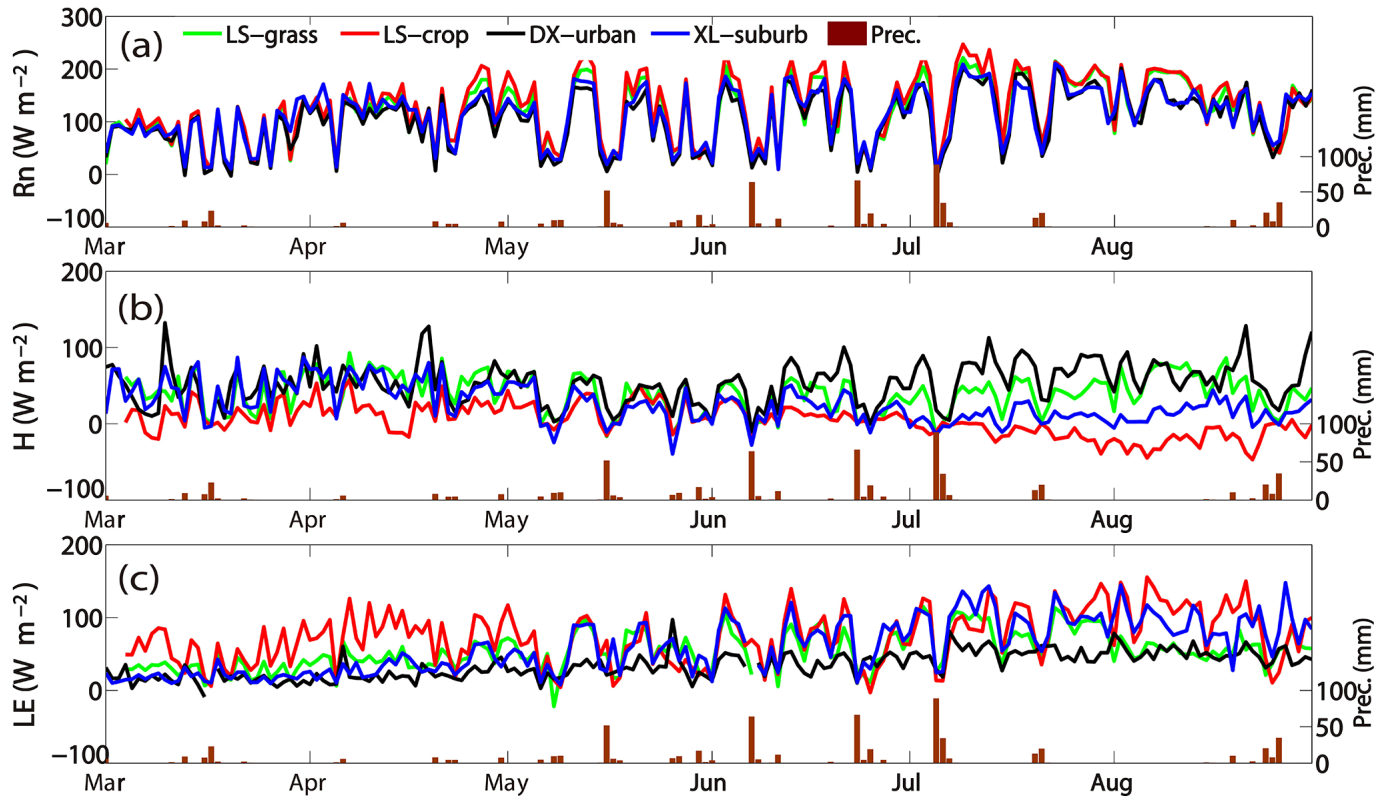

Figure 7. Daily variations in (a) net radiation, (b) sensible heat flux, and (c) latent heat flux at the four sites in Nanjing from March to August 2013.

ues greater than $95 \mathrm{Wm}^{-2}$. LE is $55.68 \mathrm{Wm}^{-2}$ larger at the LS-site than at the DX-urban site.

Figure 9 depicts the seasonal average surface energy components. $H$ accounts for a large proportion of $R_{\mathrm{n}}$ in the spring, with the value increasing to $25.60,47.65,60.92$, and
$75.45 \%$ at the LS-crop, LS-grass, XL-suburb, and DX-urban sites, respectively. In the summer, accompanied by the rainy season, vegetation thrives and the ratio of LE to $R_{\mathrm{n}}$ significantly increases. The values of this ratio are $60.01,47.18$, 66.65 , and $37.86 \%$, respectively, at the four sites. Again, ef- 

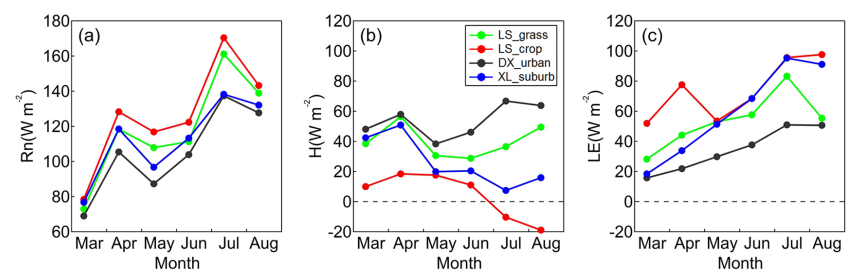

Figure 8. Monthly variation in (a) net radiation, (b) sensible heat flux, and (c) latent heat flux at the four sites in Nanjing from March to August 2013.
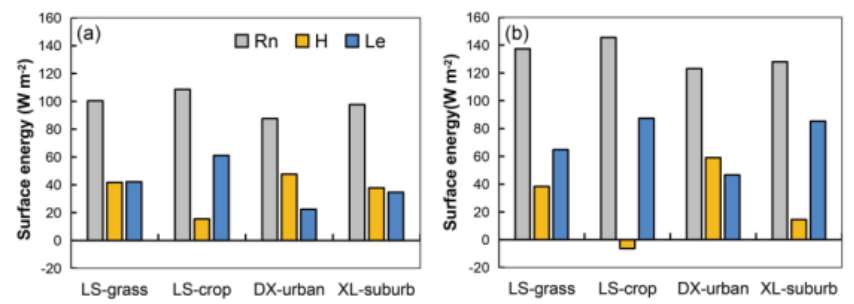

Figure 9. Seasonal average distribution of surface energy for the (a) spring and (b) summer at the four sites in Nanjing.

fects of the woodlands surrounding the XL-suburb site are reflected in the measurements at XL-suburb. The negative sensible heat flux is attributed to the negative difference in air temperature and surface temperature (Table 1) at the LScrop site.

Figure 10 shows the diurnal variations in net radiation, sensible heat flux, and latent heat flux for the spring and summer at the four sites. $R_{\mathrm{n}}$ is negative during nighttime, and the maximum value occurs at around 14:00 in the daytime. The differences in peak value of $R_{\mathrm{n}}$ between the spring and summer are larger than $50 \mathrm{Wm}^{-2}$ at all the four sites. Except for the DX-urban site, the difference in maximum $H$ between the spring and summer is greater than $30 \mathrm{Wm}^{-2}$ at the other three sites. The difference in the peak value of LE between the spring and summer is larger than $60 \mathrm{Wm}^{-2}$. At the DXurban site, $H$ is always larger than LE in both the spring and summer. Figure 10b shows clearly that the peak value of $H$ is largest at the XL-suburb site in the spring, and at the DXurban site in the summer. The differences between these two sites and the LS-crop site are 92.53 and $162.21 \mathrm{Wm}^{-2}$, respectively. The peak value of $H$ is the smallest at the LScrop site, and $H$ can be negative during the entire day in the summer. This is because the LS-crop site is covered by water in the summer, and the large evaporation results in low surface temperature that is lower than air temperature (Lee et al., 2004). For both the spring and summer, the peak value of LE remains largest at the LS-crop site and smallest at the DX-urban site. The difference in LE between the two sites can be up to $138.46 \mathrm{Wm}^{-2}$ in the spring and $156.46 \mathrm{Wm}^{-2}$ in the summer. This result suggests that there exist distinct differences in radiation and surface energy fluxes over differ- ent underlying surface types in not only the semiarid region (Wang et al, 2010; Li et al., 2015) but also the monsoon region of the mid- to lower reaches of the Yangtze River valley.

\subsection{Mechanism analysis}

Changes in the surface characteristics are always accompanied by variations in the parameters involved in land surface process. Differences in characteristic parameters such as albedo, Bowen ratio, and roughness length affect radiation and energy distribution, which subsequently feed back to the atmosphere and affect micrometeorology in the surface layer (Amiro et al., 2006; Lee et al., 2011).

\subsubsection{Radiation and turbulent exchange coefficients}

In land surface processes, albedo is a basic parameter that affects net radiation in the surface (Li et al., 2015; Krishnan et al., 2012; Zhang et al., 2014). Daily variations in albedo at three sites with vegetation (Fig. 11a) show that albedo decreases with the growing of vegetation from March to midMay, remains stable in June, and then slightly increases until August because of a lack of precipitation. The rapid decrease is found at the LS-crop site with the largest daily decrease of 0.13 . At the beginning of June, albedo decreases to less than 0.09 due to straw burning and later remains less than 0.1 due to irrigation. From mid-July, the albedo at the LScrop site gradually increases to 0.15 , accompanied by the growing of rice, and becomes close to that at the DX-urban and XL-suburb sites. At the DX-urban site, there is no large daily variation in albedo, which remains at around 0.13 . Furthermore, there exists a high correlation between albedo and precipitation for the DX-urban and LS-crop sites but not LSgrass or XL-suburb. The roof of the building on which we built the flux tower is watertight in the city, and the soil with sparse vegetation cover has high level of wetness in cropland. After precipitation, waterlogging occurs at both of these two sites, which causes the high albedo in a short time.

The difference in albedo determines the daily USR variation at the four sites (Fig. 4b). Figure 12 shows that, except for the XL-suburb site, the albedo at the other three sites decreases from spring to summer. At the XL-suburb site, possibly because of insufficient precipitation after mid-July, the summer albedo increases and becomes slightly larger than that in the spring. However, at the grassland site, the albedo decreases largely in the green-up phrase, which results in the lower albedo in summer. In addition, the dramatic decrease in surface albedo in early June is associated with biomass burning due to the cultivation system in this region, i.e., a rotation of wheat in winter and rice in summer. Even with the influence of irrigation and albedo increase, however, the radiative forcing still leads to an increase in surface temperature. In the boreal region, however, model studies and field experiments (Defries et al., 2002; Lee et al., 2011) have both revealed that degradation of vegetation represented by deforestation could 

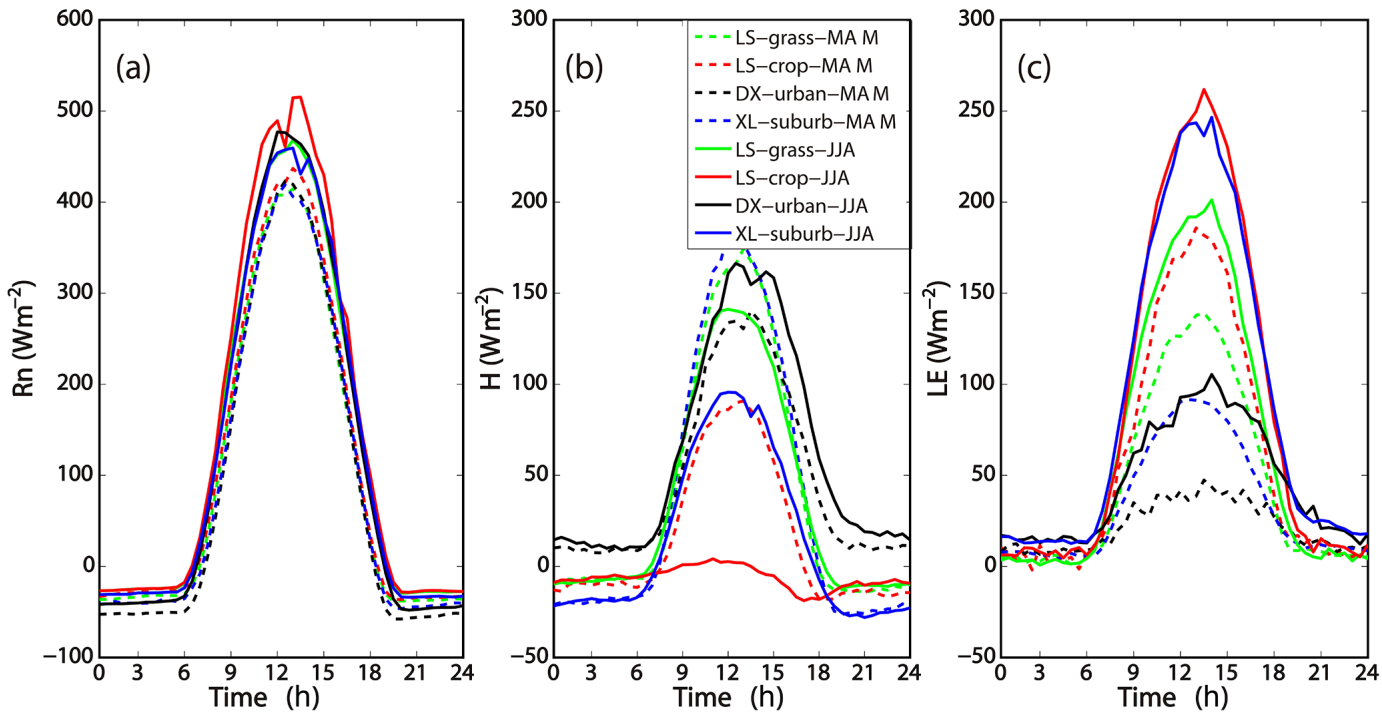

Figure 10. Diurnal variation in (a) net radiation, (b) sensible heat flux, and (c) latent heat flux at the four sites in Nanjing from March to August 2013.
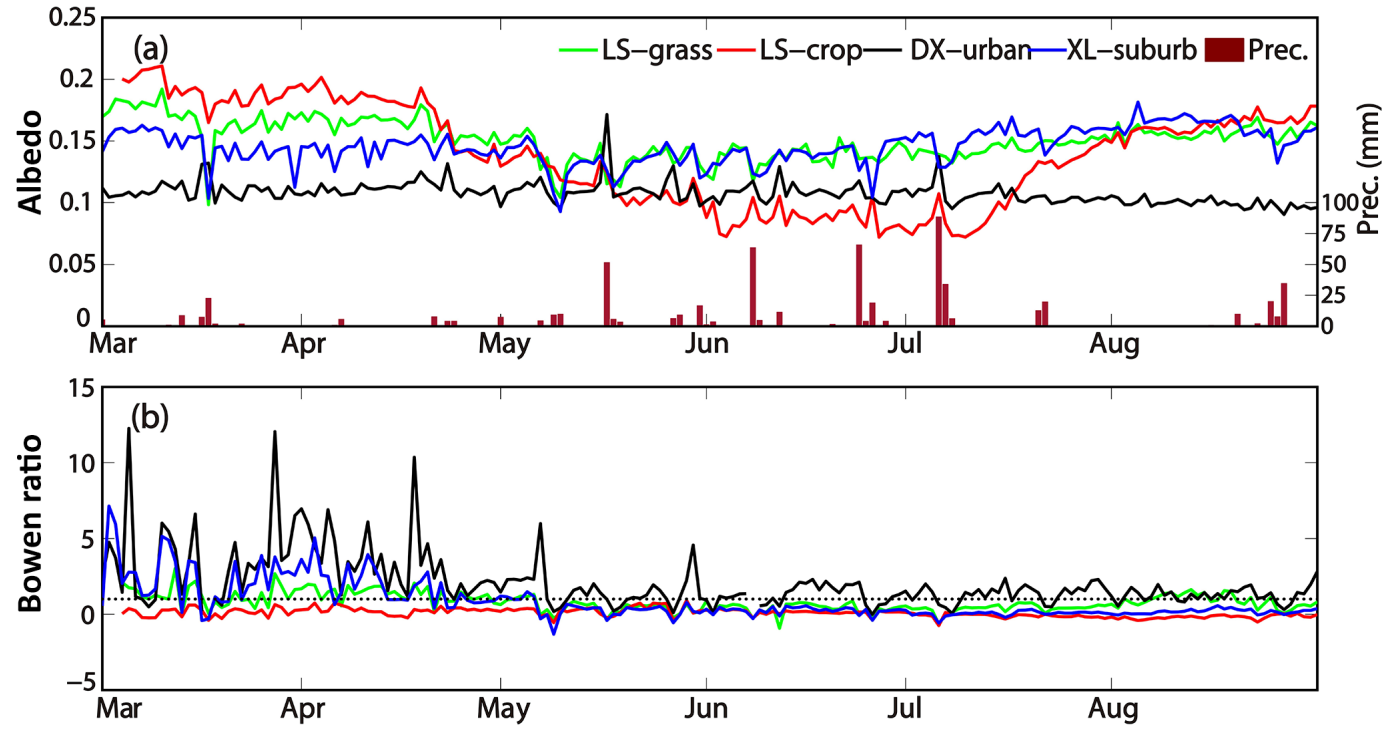

Figure 11. Daily variation in (a) albedo and (b) Bowen ratio at the four sites in Nanjing from March to August 2013.

lead to lower surface temperature. This is quite different from the situation in temperate and tropical regions. Thereby, the warming and cooling trends might be different over regions with different surface types and background climate, which makes it important to conduct a mechanism study for the impact of different land cover types on local temperature.

The Bowen ratio is the measure of surface energy distribution. It reflects the dry and wet condition of the surface to a certain degree (Li et al., 2015; Wang et al., 2010). The daily variation in the Bowen ratio (Fig. 11b) indicates that large variation occurs in the spring and there exist distinct differences between the four sites. The difference between the DX-urban and LS-crop sites is larger than 10 at the beginning of March. The differences between the four sites and the variation at each site both decrease during the rainy season. Except for the DX-urban site, the Bowen ratio is smaller than 1.0 from early May onwards at all sites and LE becomes dominant. Considering the surface types at the four sites, it is found that daily variation in the Bowen ratio is small (stable) at the surface with large vegetation cover fraction and high soil moisture content, which is more capable of adjusting the heat and water balance. This result is consistent with that for the semiarid region (Hu et al., 2009). Figure 12b suggests that, with more precipitation and large vegetation cover 

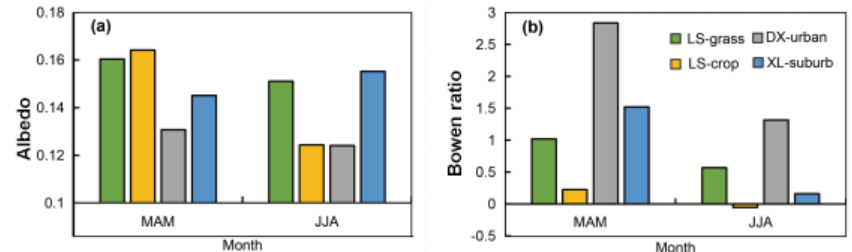

Figure 12. Seasonal averages of (a) albedo and (b) the Bowen ratio for the spring and summer at the four sites in Nanjing.

fraction in the summer, the Bowen ratio is much smaller in the summer than in the spring. Comparing the Bowen ratio at the four sites, the largest value is found at the DX-urban site, while the smallest is at the LS-crop site for both the spring and summer. The negative sensible heat flux at the LS-crop site in the summer causes the Bowen ratio to be less than zero. At the XL-suburb site, $H / \mathrm{LE}$ further decreases due to the effects of woodlands nearby, while $\mathrm{LE} / R_{\mathrm{n}}$ further increases and accounts for a larger proportion in the energy distribution (Fig. 9b).

Generally speaking, LE accounts for a large proportion of $R_{\mathrm{n}}$ at sites where the Bowen ratio is small. The relative humidity is affected by temperature and water vapor content, which is essentially shown in the mid- to lower reaches of the Yangtze River valley, but relative humidity would not be entirely analyzed without considering the influence of advection because of data limitation.

\subsubsection{Surface roughness length in different surface types}

Surface roughness length is an important ecological and land surface parameter. The spring-summer average roughness length at the DX-urban site calculated based on the shape of the surface roughness elements is $2.82 \mathrm{~m}$, which has no distinct seasonal variation. Monthly variations in surface roughness length at the other three sites are shown in Fig. 13, which shows that the roughness length basically increases with the month from May to August. The differences in roughness length between the four sites are largely caused by the differences in vegetation cover, which are rice, grass, and lawn at the LS-crop, LS-grass, and XL-suburb sites, respectively. The average roughness lengths of the growing season are $0.02,0.05$, and $0.17 \mathrm{~m}$, respectively, at these three sites. Apparently the roughness length at the XL-suburb site more reflects the characteristics of the woodlands nearby. The roughness length decreases slightly in July at the XL-suburb and LS-grass sites due to insufficient precipitation. In early June after the harvest of winter wheat, the roughness length at the LS-crop is less than $0.01 \mathrm{~m}$, but it gradually increases later with the growth of rice.

Figure 14 shows that from the spring to summer, the increase in roughness length at the XL-suburb site is much larger than that at the LS-grass site, and the differences be-

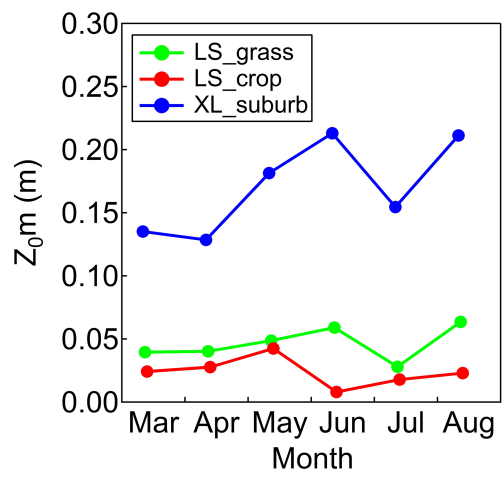

Figure 13. Monthly variations in surface roughness length at the three sites in Nanjing from March to August 2013.

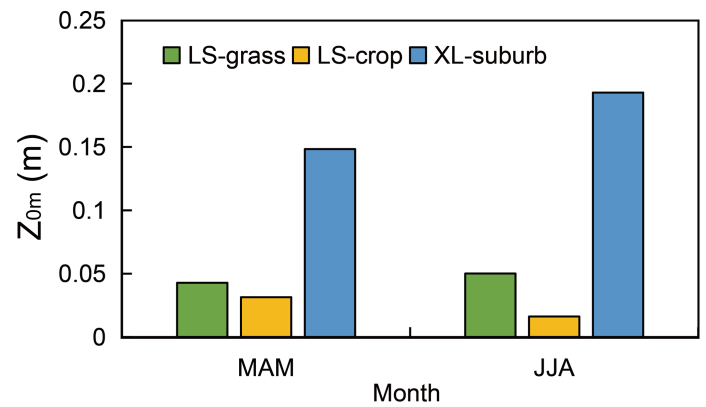

Figure 14. Seasonal averages of surface roughness length at the four sites in Nanjing for the spring and summer of 2013.

tween the spring and summer at the two sites are 0.045 and $0.007 \mathrm{~m}$, respectively. This is attributed to the differences in vegetation type and height. This result indicates that different land use types and roughness element heights are responsible for the different roughness length at various timescales.

Comparing results at the LS-grass and XL-suburb sites, both of which are covered by natural vegetation, it can be found that the vegetation with a larger roughness length can promote stronger turbulent flux transfer and has a higher capability to adjust temperature. This explains why average temperature and diurnal temperature range are both relatively small at the XL-suburb site, despite the high surface temperature at this site (Fig. 3a). Sensitivity experiments of a numerical model study also demonstrated that the surface roughness length is one of the most sensitive factors for landatmosphere exchange (Liu et al., 2015).

\section{Conclusions}

The year 2013 is a typical dry and hot year. During the growing season in the mid- to lower reaches of the Yangtze River valley monsoon region, the four different surface types, i.e. urban surface, woodland, grassland, and cropland, can directly affect the surface radiation balance and landatmosphere exchanges of heat, water vapor, and mass fluxes 
and subsequently affect local climate. In the present study, we have revealed the differences in several physical parameters between the four typical surface types mentioned above during the study period and explored the mechanisms for the differences.

Daily variations in the micrometeorological elements at the four sites are different due to different surface characteristics. The differences in micrometeorological elements are more distinct during the dry and hot period. The differences between the DX-urban and LS-crop sites are the most significant. The largest differences in air temperature, surface temperature, and relative humidity between the two sites are $3.21,7.26^{\circ} \mathrm{C}$, and $22.79 \%$, respectively. Compared with natural vegetation cover (LS-grass and XL-suburb sites), albedo at urban surface is smaller and thus the radiative forcing is stronger, leading to higher surface temperature. However, insufficient moisture content causes the Bowen ratio to be large. Hence, the surface heat is transferred to the atmosphere mainly in the form of sensible heat flux, and air temperature is high while relative humidity is small. At the same time, the urban heat island effect results in higher surface $T_{\mathrm{a}}$ and $T_{\mathrm{s}}$ in the nighttime at the DX-urban site that are $2{ }^{\circ} \mathrm{C}$ higher than at other sites, and the diurnal temperature range is small. In Lishui County, the crops were not stressed by lack of moisture or high temperatures during the growing period due to irrigation, so latent heat flux dominates the land-atmosphere heat flux exchange. Surface temperature and air temperature both are relatively low, while the relative humidity is relatively large due to large evaporation at the surface. Surface albedo reaches its smallest value in June because of wheat harvest and straw burning at this time. Daily variation in USR increases under the influence of albedo. For both spring and summer, the peak values of diurnal variation in surface temperature and diurnal temperature range are the smallest at the LS-crop site, mainly because the sufficient soil moisture content at this site acts to lower the surface temperature. Negative sensible heat flux is found at this site in the summer due to the large evaporation. Compared with the situation over surface types with natural vegetation cover, the peak value in the diurnal variation in surface temperature and its diurnal range are both large at the XL-suburb site, where the vegetation cover fraction is low. However, the woodland nearby the XL-suburb promotes turbulent exchange and heat flux transfer, leading to lower air temperature and diurnal range. From the spring to summer, the latent heat flux becomes dominant with the increase in albedo, and the Bowen ratio gradually decreases to less than 1. Diurnal ranges of air temperature, surface temperature, and relative humidity all gradually decrease.

Under the same climate background, changes in surface albedo result in changes in the radiative forcing. The Bowen ratio change caused by the surface energy distribution and the aerodynamic resistance change related to surface roughness length jointly determine the differences in surface temperature, air temperature, and relative humidity between differ- ent land surface types with various types of vegetation cover. The monsoon precipitation and land use changes resulting from human activities make the land-atmosphere interaction more complicated. Compared with the situation at sites with natural vegetation cover, air temperature at the XL-suburb site is lower than that at the LS-grass site, whereas the surface temperature is higher than that at the LS-grass site. Such an inconsistency is caused by the complexity in the surface characteristics. The present study has investigated the features and mechanisms of land-atmosphere interaction over four different surface types. However, contributions of various land surface parameters to micrometeorological elements are different, and further quantitative analysis of the contribution of each individual parameter is necessary.

Acknowledgements. This research is jointly sponsored by the Natural Science Foundation of China (grant no. 41475063, 91544231), the National Science and Technology Support Program (2014BAC22B04), and Program for New Century Excellent Talents in University. This work is also supported by the Jiangsu Collaborative Innovation Center for Climate Change.

Edited by: J. Huang

Reviewed by: two anonymous referees

\section{References}

Amiro, B. D., Barr, A. G., Black, T. A., Iwashitad, H., Kljun, N., McCaughey, J. H., Morgenstern, K., Murayama, S., Nesic, Z., Orchansky, A. L., and Saigusa, N.: Carbon, energy and water fluxes at mature and disturbed forest sites, Saskatchewan, Canada, Agr. Forest. Meteorol., 136, 237-251, doi:10.1016/j.agrformet.2004.11.012, 2006.

Alberto, M. C. R., Wassmann, R., Hirano, T., Miyata, A., Arvind, K., Padre, A., and Amante, M.: $\mathrm{CO}_{2}$ /heat fluxes in rice fields: Comparative assessment of flooded and non-flooded fields in the Philippines, Agr. Forest Meteorol. 149, 1737-1750, doi:10.1016/j.agrformet.2009.06.003, 2009.

Alberto, M. C. R., Wassmann R., Hirano T., Miyata A., Hatano R., Kumar A., Padre A., and Amante M.: Comparisons of energy balance and evapotranspiration between flooded and aerobic rice fields in the Philippines, Agr. Water Manag., 98, 1417-1430, doi:10.1016/j.agwat.2011.04.011, 2011.

Arnfield, A. J.: Two decades of urban climate research: A review of turbulence, exchanges of energy and water, and the urban heat island, Int. J. Climatol., 23, 1-26, doi:10.1002/joc.859, 2003.

Baldocchi, D. D.: Biogeochemistry: Managing land and climate, Nature Climate Change, 4, 330-331, doi:10.1038/nclimate2221, 2014.

Baldocchi, D. D. and Rao, K. S.: Intra-field variability of scalar flux densities across a transition between a desert and an irrigated potato field, Bound.-Lay. Meteorol., 76, 109-136, doi:10.1007/bf00710893, 1995.

Baldocchi, D. D. and Ma, S.: How will land use affect air temperature in the surface boundary layer? Lessons learned from a comparative study on the energy balance of an oak savanna 
and annual grassland in California, USA, Tellus B, 65, 19994, doi:10.3402/tellusb.v65i0.19994, 2013.

Baldocchi, D. D., Falge, E, Gu, L. H., Olson., R., Hollinger, D., Running, S., Anthoni, P., Bernhofer, C., Davis, K., Evans, R., Fuentes., J., Goldstein, A., Katul, G., Law, B., Lee, X. H., Malhi, Y., Meyers, T., Munger, W., Oechel, W., Paw U, K. T., Pilegaard, K., Schmid, H. P., Valentini, R., Verma, S., Vesala, T., Wilson, K., and Wofsy, S.: FLUXNET: A new tool to study the temporal and spatial variability of ecosystem-scale carbon dioxide, water vapor, and energy flux densities, B. Am. Meteorol. Soc., 82, 2415-2434, 2001.

Baldocchi, D. D., Xu, L., and Kiang N.: How plant functionaltype, weather, seasonal drought, and soil physical properties alter water and energy fluxes of an oak-grass savanna and an annual grassland, Agr. Forest. Meteorol., 123, 13-39, doi:10.1016/j.agrformet.2003.11.006, 2004.

Bi, X., Gao, Z., Deng, X., Wu, D., Liang, J., Zhang, H., Sparrow, M., Du, J., Li, F., and Tan, H.: Seasonal and diurnal variations in moisture, heat, and $\mathrm{CO}_{2}$ fluxes over grassland in the tropical monsoon region of southern China, J. Geophys. Res., 112, D10106, doi:10.1029/2006jd007889, 2007.

Bonan, G. B.: Forests and climate change: forcings, feedbacks, and the climate benefits from the forests, Science 320, 1444-1449, doi:10.1126/science.1155121, 2008

Bounoua, L., DeFries, R., Collatz, G. J., Sellers, P., and Khan, H.: Effects of land cover conversion on surface climate, Climate Change, 52, 29-64, doi:10.1023/a:1013051420309, 2002.

Brown, M., Black, T. A., Nesic, Z., Foord, V. N., Spittlehouse, D. L., Fredeen, A. L., Grant, N. J., Burton, P. J., and Trofymow, J. A.: Impact of mountain pine beetle on the net ecosystem production of lodgepole pine stands in British Columbia, Agr. Forest. Meteorol., 150, 254-264, doi:10.1016/j.agrformet.2009.11.008, 2010.

Burba, G. G., Verma, S. B., and Kim, J.: Surface energy fluxes of Phragmites australis in a prairie wetland, Agr. Forest. Meteorol., 94, 31-51, doi:10.1016/s0168-1923(99)00007-6, 1999.

Chen, J., Wang, J, and Mitsuta, Y.: An independent method to determine the surface roughness length (in Chinese), Chinese J. Atmos. Sci., 17, 21-26, 1993.

Chen, X., Su, Z., Ma, Y., Liu, S., Yu, Q., and Xu, Z.: Development of a 10-year (2001-2010) $0.1^{\circ}$ data set of land-surface energy balance for mainland China, Atmos. Chem. Phys., 14, 1309713117, doi:10.5194/acp-14-13097-2014, 2014.

Coulter, R. L., Pekour, M. S., and Cook. D. R.: Surface energy and carbon dioxide fluxes above different vegetation types within ABLE, Agr. Forest. Meteorol., 136, 147-158, doi:10.1016/j.agrformet.2004.11.011, 2006.

Davin, E. L. and De Noblet-Ducoudré, N.: Climatic impact of global-scale deforestation: radiative versus nonradiative processes, J. Climate, 23, 97-112, doi:10.1175/2009jcli3102.1, 2010.

Defries, R. S., Bounoua, L., and Collatz, G. J.: Human modification of the landscape and surface climate in the next fifty years, Glob. Change Biol., 8, 438-458, doi:10.1046/j.13652486.2002.00483.x, 2002.

Ding, A. J., Fu, C. B., Yang, X. Q., Sun, J. N., Petäjä, T., Kerminen, V.-M., Wang, T., Xie, Y., Herrmann, E., Zheng, L. F., Nie, W., Liu, Q., Wei, X. L., and Kulmala, M.: Intense atmospheric pollution modifies weather: a case of mixed biomass burning with fossil fuel combustion pollution in eastern China, Atmos. Chem. Phys., 13, 10545-10554, doi:10.5194/acp-13-10545-2013, 2013.

Feddema, J. J., Oleson, K. W., Bonan, G., Mearns, L. O., Buja, L. E., Meehl, G. A., and Washington, W. M.: The importance of land-cover change in simulating future climates, Science, 310 , 1674-1678, doi:10.1126/science.1118160, 2005.

Feng, J. W., Liu, H. Z., and Wang, L.: Seasonal and inter-annual variation of surface roughness length and bulk transfer coefficients in semiarid area, Sci. China Earth Sci., 55, 254-261, doi:10.1007/s11430-011-4258-2, 2012.

Foken, T., Göockede, M., Mauder, M., Mahrt, L., Amiro, B., and Munger, W. : Post-Field Data Quality Control, Handbook of micrometeorology: a guide for surface flux measurement and analysis, 181-208, 2004.

Fu, C. B. and Yuan, H. L.: An virtual numerical experiment to understand the impacts of recovering natural vegetation on the summer climate and environmental conditions in East Asia, Chinese Sci. Bull. 46, 1199-1203, doi:10.1007/bf02900602, 2001.

Gao, X. J., Luo, Y., Lin, W. T., Zhao, Z. C., and Giorgi, F.: Simulation of effects of land use change on climate in China by a regional climate model, Adv. Atmos. Sci. 20, 583-592, doi:10.1007/s11430-007-2060-y, 2003.

Guan, X., Huang, J., Guo, N., Bi., J, and Wang, G.: Variability of soil moisture and its relationship with surface albedo and soil thermal parameters over the Loess Plateau, Adv. Atmos. Sci., 26, 692-700, doi:10.1007/s00376-009-8198-0, 2009.

Han, X. and He, L.: Analysis of Abnormal High Temperature Causes in the Summer of 2013, Climate Change Research Letters, 03, 78-84, doi:10.12677/ccrl.2014.32012, 2014.

Harazono, Y., Kim, J., Miyata, A., Choi, T., Yun, J. I., and Kim, J. W.: Measurement of energy budget components during the International Rice Experiment (IREX) in Japan, Hydrol. Process., 12, 2081-2092, 1998.

Hu, Z. M., Yu, G. R., Zhou, Y. L., Sun, X. M., Li, Y. N., Shi, P. L., Wang, Y. F., Song, X., Zheng, Z. M., Zhang, L., and Li, S. G.: Partitioning of evapotranspiration and its controls in four grassland ecosystems: application of a two-source model, Agr. Forest. Meteorol., 149, 1410-1420, doi:10.1016/j.agrformet.2009.03.014, 2009.

Huang, J., Zhang, W., Zuo, J., Bi, J., Shi, J., Wang, X., Chang, Z., Huang, Z., Yang, S., Zhang, B., Wang, G., Feng, G., Yuan, J., Zhang, L., Zuo, H., Wang, S., Fu, C., and Chou, J.: An overview of the semi-arid climate and environment research observatory over the Loess Plateau, Adv. Atmos. Sci., 25, 906-921, doi:10.1007/s00376-008-0906-7, 2008.

Huang, J., Yu, H., Guan, X., Wang, G., and Guo, R.: Accelerated dryland expansion under climate change, Nature Climate Change, 1.6, 166-171, doi:10.1038/nclimate2837, 2016.

Hsu, H.-H. and Liu, X.: Relationship between the Tibetan Plateau heating and East Asian summer monsoon rainfall, Geophys. Res. Lett., 30, 1182-1200, doi:10.1029/2003g1017909, 2003.

Intergovernmental Panel on Climate Change: Climate Change 2013: The Physical Science Basis, in: Contribution of Working Group I to the Fifth Assessment Report of the Intergovernmental Panel on Climate Change, edited by: Stocker, T. F., Qin, D., Plattner, G.-K., Tignor, M., Allen, S. K., Boschung, J., Nauels, A., Xia, Y., Bex, V., and Midgley, P. M., Cambridge University Press, Cambridge, United Kingdom and New York, NY, USA, 1535, 2013. 
Jin, Y. and Roy, P. D.: Fire-induced albedo change and its radiative forcing at the surface in northern Australia, Geophys. Res. Lett. 32, L13401, doi:10.1029/2005g1022822, 2005.

Kalnay, E. and Cai, M.: Impact of urbanization and land-use change on climate, Nature, 423, 528-531, doi:10.1038/nature01675, 2003.

Krishnan, P., Meyers, T. P., Scott, R. L., Kennedy, L., and Heuer, M.: Energy exchange and evapotranspiration over two temperate semi-arid grasslands in North America, Agr. Forest. Meteorol., 153, 31-44, doi:10.1016/j.agrformet.2011.09.017, 2012.

Lawrence, P. J., Feddema, J. J., and Bonan, G. B.: Simulating the biogeochemical and biogeophysical impacts of transient land cover change and wood harvest in the Community Climate System Model (CCSM4) from 1850 to 2100, J. Climate, 25, 30713095, doi:10.1175/jcli-d-11-00256.1, 2012.

Lee, E., Barford, C., Kucharik, C., Felzer, B., and Foley, J.: Role of turbulent heat fluxes over land in the monsoon over East Asia, Int. J. Geosci., 2, 420-431, doi:10.4236/ijg.2011.24046, 2011.

Lee, X., Qiang, Y., Sun, X., Liu, J., Min, Q., Liu, Y., and Zhang, X.: Micrometeorological fluxes under the influence of regional and local advection: a revisit, Agr. Forest. Meteorol., 122, 111-124, doi:10.1016/j.agrformet.2003.02.001, 2004.

Lee, X., Goulden, M. L., and Hollinger, D. Y.: Observed increase in local cooling effect of deforestation at higher latitudes, Nature, 479, 384-387, doi:10.1038/nature10588, 2011.

Li, Y. J., Zhou, L., Xu, Z. Z., and Zhou, G. S.: Comparison of water vapor, heat and energy exchanges over agricultural and wetland ecosystems, Hydrol. Processes, 23, 2069-2080, doi:10.1002/hyp.7339, 2009.

Li, H. Y., Fu, C. B., Guo, W. D., and Ma, F.: Study of energy partitioning and its feedback on the microclimate over different surfaces in an arid zone (in Chinese), Acta Phys. Sin., 64, 5920159201, doi:10.7498/aps.64.059201, 2015.

Lin, W., Zhang, L., Du, D., Yang, L., Lin, H., Zhang, Y., and Li, J.: Quantification of land use/land cover changes in Pearl River Delta and its impact on regional climate in summer using numerical modeling, Reg. Environ. Change, 9, 75-82, doi:10.1007/s10113-008-0057-5, 2009.

Liu, Y., Guo, W. D., and Song, Y. M.: Estimation of key surface parameters in semi-arid region and their impacts on improvement of surface fluxes simulation, Sci. China Earth Sci., 59, 113, doi:10.1007/s11430-015-5140-4, 2015.

Lohila, A., Minkkinen, K., and Laine, J.: Forestation of boreal peatlands: impacts of changing albedo and greenhouse gas fluxes on radiative forcing, J. Geophys. Res., 115, G04011, doi:10.1029/2010jg001327, 2010.

Luyssaert, S., Jammet, M., and Stoy, P. C.: Land management and land-cover change have impacts of similar magnitude on surface temperature, Nature Climate Change, 4, 389-393, doi:10.1038/nclimate2196, 2014.

Masseroni, D., Facchi, A., Romani, M., Chiaradia, E. A., Gharsallah, O., and Gandolfi, C.: Surface energy flux measurements in a flooded and an aerobic rice field using a single eddy-covariance system, Paddy Water Environ., 13, 405-424, doi:10.1007/s10333-014-0460-0, 2014

Montes-Helu, M. C., Kolb, T., Dore, S., Sullivan, B., Hart, S. C., Koch, G., and Hungate, B. A.: Persistent effects of fire-induced vegetation change on energy partitioning and evapotranspiration in ponderosa pine forests, Agr. Forest. Meteorol., 149, 491-500, doi:10.1016/j.agrformet.2008.09.011, 2009.

Moore, C. J.: Frequency response corrections for eddy correlation systems, Bound. Lay. Meteorol., 37, 17-35, doi:10.1007/BF00122754, 1986.

McAlpine, C. A., Syktus, J., Ryan, J. G., Deo, R. C., and Mckeon, G. M.: A continent under stress: interactions, feedbacks and risks associated with impact of modified land cover on Australia's climate, Glob. Change Biol., 15, 2206-2223, doi:10.1111/j.13652486.2009.01939.x, 2009.

Offerle, B., Grimmond, C., Fortuniak, K., and Pawlak, W.: Intraurban differences of surface energy fluxes in a central european city, J. Appl. Meteorol. Climatol., 45, 125-136, doi:10.1175/jam2319.1, 2006.

Oke, T. R. and Cleugh, H. A.: Urban heat storage derived as energy balance residuals, Bound. Lay. Meteorol., 39, 233-245, doi:10.1007/bf00116120, 1987.

Pielke, R. A., Marland, G., Betts, R. A., Chase, T. N., Eastman, J. L., Niles, J. O., Niyogi, D. D. S., and Running, S. W.: The influence of land-use change and landscape dynamics on the climate system: relevance to climate-change policy beyond the radiative effect of greenhouse gases, Philos. Trans. A, 360, 1705-1719, doi:10.1098/rsta.2002.1027, 2002.

Pitman, A. J., Noblet-Ducoudré, N. D., Cruz, F. T., Davin, E. L., Bonan, G. B., Brovkin, V., Claussen, M., Delire, C., Ganzeveld, L., Gayler, V., van den Hurk, B. J. J. M., Lawrence, P. J., van der Molen, M. K., Müller, C., Reick, C. H., Seneviratne, S. I., Strengers, B. J., and Volodoire, A.: Uncertainties in climate responses to past land cover change: First results from the LUCID inter-comparison study, Geophys. Res. Lett, 36, L14814, doi:10.1029/2009g1039076, 2009.

Prueger, J. H., Kustas, W. P., Hipps, L. E., and Hatfield, J. L.: Aerodynamic parameters and sensible heat flux estimates for a semi-arid ecosystem, J. Arid. Environ., 57, 87-100, doi:10.1016/s0140-1963(03)00090-9, 2004.

Qiu, J.: Monsoon Melee, Science, 340, 1400-1401, doi:10.1126/science.340.6139.1400, 2013.

Reale, O. and Dirmeyer, P.: Modeling the effects of vegetation on Mediterranean climate during the Roman Classical Period, Part I: Climate history and model sensitivity, Global Planet. Change, 25, 163-184, doi:10.1016/S0921-8181(00)00002-3, 2000.

Sanderson, E. W., Jaiteh, M., Levy, M. A., Redford, K. H., Wannebo, A. V., and Woolmer, G.: The human footprint and the last of the wild, Bioscience, 52, 891-904, doi:10.1641/00063568(2002)052[0891:thfatl]2.0.co;2, 2002.

Suh, M.-S. and Lee, D.-K.: Impacts of land use/cover changes on surface climate over east Asia for extreme climate cases using RegCM2, J. Geophys. Res.-Atmos., 109, D02108, doi:10.1029/2003jd003681, 2004.

Wang, G. Y., Huang, J. P., Guo, W. D., Zuo, J. Q., Wang, J. M., Bi, J. R., Huang, Z. W., and Shi, J. S.: Observation analysis of land-atmosphere interactions over the Loess Plateau of northwest China, J. Geophys. Res., 115, D00K17, doi:10.1029/2009jd013372, 2010.

Wang, Q. and Eleuterio, D. P.: A comparison of bulk aerodynamic methods for calculating air-sea fluxes, paper presented at Ninth Conference on Mesoscale Processes, Am. Meteorol. Soc., Fort Lauderdale, Fla., 2001. 
Wang, S., Zhang, Q., and Wei, G. A.: Analyses on Characters of Surface Radiation and Energy at Oasis-Desert Transition Zone in Dunhuang (in Chinese), Plateau Meteorol., 24, 556-562, 2005.

Wang, Y., Sang, Y. Y., and Zhang L. F.: Circulation anomaly of summer high temperature and drought in Zhejiang of 2013, J. Meteorol. Sci., 35, 140-149, doi:10.3969/2014jms.0086, 2015.

Werth, D. and Avissar, R.: The local and global effects of Amazon deforestation, J. Geophys. Res., 107, 8087, doi:10.1029/2001jd000717, 2002.

Wilczak, J. M., Oncley, S. P., and Stage, S.A., Sonic anemometer tilt correction algorithms, Bound. Lay. Meteorol., 99, 127-150, doi:10.1023/A:1018966204465, 2001.

Xue, Y.: The Impact of Desertification in the Mongolian and the Inner Mongolian Grassland on the Regional Climate, J. Climate, 9, 2173-2189, 1996.

Xue, Y., Juang, H.-M. H., Li, W., Prince, S., DeFries, R., Jiao, Y., and Vasic, R.: Role of land surface processes in monsoon development: East Asia and West Africa, J. Geophys. Res., 109, 215-229, doi:10.1029/2003jd003556, 2004.

Yuan, W., Cai, W., Chen, Y., Liu, S., Dong, W., Zhang, H., Yu, G., Chen, Z., He, H., Guo, W., Liu, D., Liu, S., Xiang, W., Xie, Z., Zhao, Z., and Zhou, G.: Severe summer heatwave and drought strongly reduced carbon uptake in Southern China, Sci. Rep., 6, 87-90, doi:10.1038/srep18813, 2016.

Zhang, C., Chen, F., Miao, S., Li, Q., Xia, X., and Xuan, C.: Impacts of urban expansion and future green planting on summer precipitation in the Beijing metropolitan area, J. Geophys. Res.-Atmos., 114, D02116, doi:10.1029/2008jd010328, 2009.
Zhang, M., Lee, X., Yu, G., Han, S., Wang, H., Yan, J., Zhang, Y., Li, Y., Ohta, T., Hirano, T., Kim, J., Yoshifuji, N., and Wang, W.: Response of surface air temperature to small-scale land clearing across latitudes, Environ. Res. Lett., 9, 206-222, doi:10.1088/1748-9326/9/3/034002, 2014.

Zhang, Q. and Huang, R.: Water vapor exchange between soil and atmosphere over a Gobi surface near an oasis in the summer, $\mathrm{J}$. Appl. Meteorol., 43, 1917-1928, doi:10.1175/jam2171.1, 2004.

Zhang, T. T., Wen, J., Wei, Z. G., Rogier, V., Li, Z. C., Liu, R., Lv, S. N., and Chen, H.: Land-atmospheric water and energy cycle of winter wheat, Loess Plateau, China, Int. J. Climate, 34, 3044 3053, doi:10.1002/joc.3891, 2014.

Zhao, M. and Pitman, A. J.: The relative impact of regional scale land cover change and increasing $\mathrm{CO}_{2}$ over China, Adv. Atmos. Sci. 22, 58-68, doi:10.1007/bf02930870, 2005.

Zhao, Q. F., Guo, W. D., Ling, X. L., Liu, Y., Wang, G. Y., and $\mathrm{Xie}$, J.: Analysis of evapotranspiration and water budget for various land use in semi-arid areas of Tongyu, China (in Chinese), Climatic Environ. Res., 18 415-426, doi:10.3878/j.issn.10069585.2012.11203, 2013. 